\author{
Bogdan Sojkin \\ Magdalena Ankiel \\ Poznań University of Economics
}

\title{
PURCHASE DETERMINANTS OF DURABLE GOODS FOR RESIDENTS OF LARGE CITIES IN POLAND
}

The article presents an analysis of purchase determinants for individual consumers of durable goods in 6 large cities in Poland. The analysis has been based on the outcomes of consumer research carried out in the years 2016 and 2017 at Poznan University of Economics and Business, as well as on other research studies published in Polish publications. The results of the study demonstrate groups of determinants that shape the purchasing decisions of consumers of durable products, as well as their variability in years 2016 and 2017.

Keywords: purchasing behavior, purchase determinants, analysis of variance, Poland JEL Codes: D12, D31, M31

\section{Introduction}

The main objective of this article is to present a comparative analysis of the role and the importance of the purchase determinants of durable goods among residents of selected large cities in Poland (Warsaw, Wrocław, Lublin, Katowice, Białystok, and Poznań). The basic sources of information included in the article are: original material from research carried out in Poland by various research institutions, and the findings of an empirical study conducted in large cities in Poland, which was carried out systematically from 2010 by the Product Marketing Department of the Poznań University of Economics and Business in Poznań, Poland.

The empirical study presented in this article is a continuation and an extension of earlier research conducted in Poznań and the Wielkopolska Province, as well as in other large Polish cities. Earlier studies concentrated on other product categories, such as food, cosmetics, and household chemicals, and their findings are presented in various previous publications [Bartkowiak, Sojkin 2014; Sojkin, 2015; Bartkowiak, Sojkin 2015, Ankiel, Sojkin 2017; Bartkowiak, Sojkin 2017]. In the case of purchase determinants of durable goods, there are fewer articles in the literature, especially when compared to purchase determinants of food, cosmetics, and household chemicals. Also, the discussion regarding these goods and their purchasing determinants mainly focuses on the impact of three factors: price, quality, and brand (either of product, or producer), or mutual relations between those factors (i.e. price/quality). Analyses of other factors such as: product (its characteristics), or consumers and their relationship with the environment, are presented much less often. In English-based literature, this problem is also poorly covered, and in published studies in the 
field, most focus is placed on selected cultural, social, demographic, psychological, and economic factors in various distribution channels. The main drawback of the publication was a very diversified enumeration of the studied factors, in particular their number (from 6 to 20 ), problems with definitions of variables, and the structure of the purchasing process [Furaiji, Łatuszyńska, Wawrzyniak 2012, Neethikumar, Aranganatha 2014, Ramya N., Ali M 2016, Kalaiselvi 2017]. Also, researchers in this field concentrate on different product categories such as television sets, refrigerators, furniture or ovens, with the concentration on age as the main control variable for consumer behavior [Hasan 2014, Johar 2015, Mashao, Sukdeo 2018, Zalega 2017].

This article is one of the few articles that present cross-sectional characteristics of the purchase determinants of durable goods among residents of large Polish cities. It is based on the prior identification of 35 key variables that determine purchasing behavior. It should be emphasized that the question of purchase determinants is important due to the systematic increase in the number of durable goods in Polish households, as well as to consumer expectations regarding their quality, usability, and durability ${ }^{1}$.

The main goal of the research was to identify the primary purchase determinants of durable goods and show their variability in the studied cities. According to the literature in the field, as well as opinions of experts, and representatives of trade enterprises, the most often indicated groups of factors that influence consumer choices are those related to the product (its physical, functional and structural characteristics), consumer (demographic, psychological, economic, and physiological characteristics), and the environment in which the consumer operates (economic, cultural, social, and infrastructural). One can often find obvious, though not always justified, arguments that the purchase of most products is determined by price, quality, and brand [Shopping habits ... 2013; Poles are buying ... 2016]. However, empirical in-depth consumer studies do not always confirm that those variables are critical determinants of consumer decisions.

\section{Research methodology}

The study presented in this article was carried out between 2016 and 2017, in 6 major Polish cities (all over 250,000 inhabitants) located in different regions of the country. The selection of cities for research was related to the implemented project covering all regions of the country. Research was also carried out in the city of Gdańsk, but formal errors made during its implementation forced the authors to omit this city from their analyses. The size of the research sample in each city was between 350 and 550 consumers, and the research method used was a direct interview technique with a quota selection of the research unit (that included: gender, age, place of residence - district). IBM SPSS Statistics ver. 22 was used to analyze the research data. The main goal of the research was to identify the purchase determinants of durable goods, generally related to household appliances. For this purpose, a

${ }^{1}$ L. Piskiewicz, M. Radziukiewicz, Zasoby dóbr trwałych w gospodarstwach domowych, Przegląd Statystyczny, GUS, 10/2018, s. 37-55. 
set of 35 variables was assessed by consumers to identify the relative importance of each factor concerning this segment of products. Those variables were identified in the earlier phase of the research that was conducted among residents of the city of Poznan and the Wielkopolskie voivodeship. Also, the findings were verified by the results of consumer surveys carried out by other research centers, as well as by new proposals submitted by participants during the research process. As a result, a set of 35 variables was identified that represented purchasing determinants of durable goods. The importance of each variable was determined on the five-point Likert scale, and the collected data were analyzed for variation in the variability of each factor based on a one-way analysis of variance - ANOVA ${ }^{2}$ [Kowal 1998]. The ANOVA method allowed to examine the statistical significance of each factor in cities (average values for the factor) and - based on post-hoc tests - to formulate conclusions regarding the differences/similarities in the behavior of residents in the studied cities.

\section{Determinants of purchases of durable goods}

Purchases of durable goods are generally made for households and are a reflection of their needs, which generate total demand as the sum of primary, duplicative, or replacement demand. Therefore, in each of them, the role and significance of determinants can be differentiated, but this issue in the conducted research was not taken into account, and this constitutes a certain cognitive, and interpretative limitation. Therefore, the obtained results in the form of arithmetic means should be treated as aggregated values of consumer assessments without taking into account the impact of the specificity of the need generated by the premise of purchase. The obtained values for purchase determinants of durable goods in each city are presented in Figure 1. Calculated mean values as weights/importance for each factor in each city show that the most important determinants of purchase of durable goods include the following: product quality $(\bar{x}=4,33)$, price $(\bar{x}=4,33)$, usefulness of the product $(\bar{x}=4,17)$, product durability $(\bar{x}=4,15)$, functionality $(\bar{x}=4,17)$ and warranty $(\bar{x}=$ $4,11)$. In addition to the above-mentioned, the most important residents indicated as additional/complementary factors such as: improving the quality of life $(\bar{x}=4,07)$, technical parameters $(\bar{x}=4,02)$, utilization of the old product $(\bar{x}=3,97)$, technical solutions $(\bar{x}=3,88)$ and product design $(\bar{x}=3,85)$.

The lowest values were attributed to: product packaging $(\bar{x}=2,63)$, the effect of imitation $(\bar{x}=2,40)$, special occasions $(\bar{x}=2,95)$, fashion and trends $(\bar{x}=3,04)$ and product financing $(\bar{x}=3,07)$. Slightly higher values were achieved for: opinions of other people $(\bar{x}=$ $3,26)$ and ecological aspects $(\bar{x}=3,16)$. It seems that low values of the first four determinants are understandable and fully justified, while the low values attributed to friends' opinions and environmental performance may surprise in the case of durable goods.

\footnotetext{
${ }^{2}$ Values on the Likert scale: value 1 meant 'no significance', value 2 is 'irrelevant (not important)' factor, value 3 is 'moderately important (neither significant nor negligible)', value 4 is a 'significant (important) factor' while value 5 defined the factor as 'decisive (most important)'.
} 
According to different studies and practical experience, Word of Mouth Marketing is a significant element of marketing communication in building a product and brand image of durable goods. Also, it is believed that the ecological character of the product is now a social value, and as such, it constitutes an important part of the decision-making process. Our data does not support those notions.

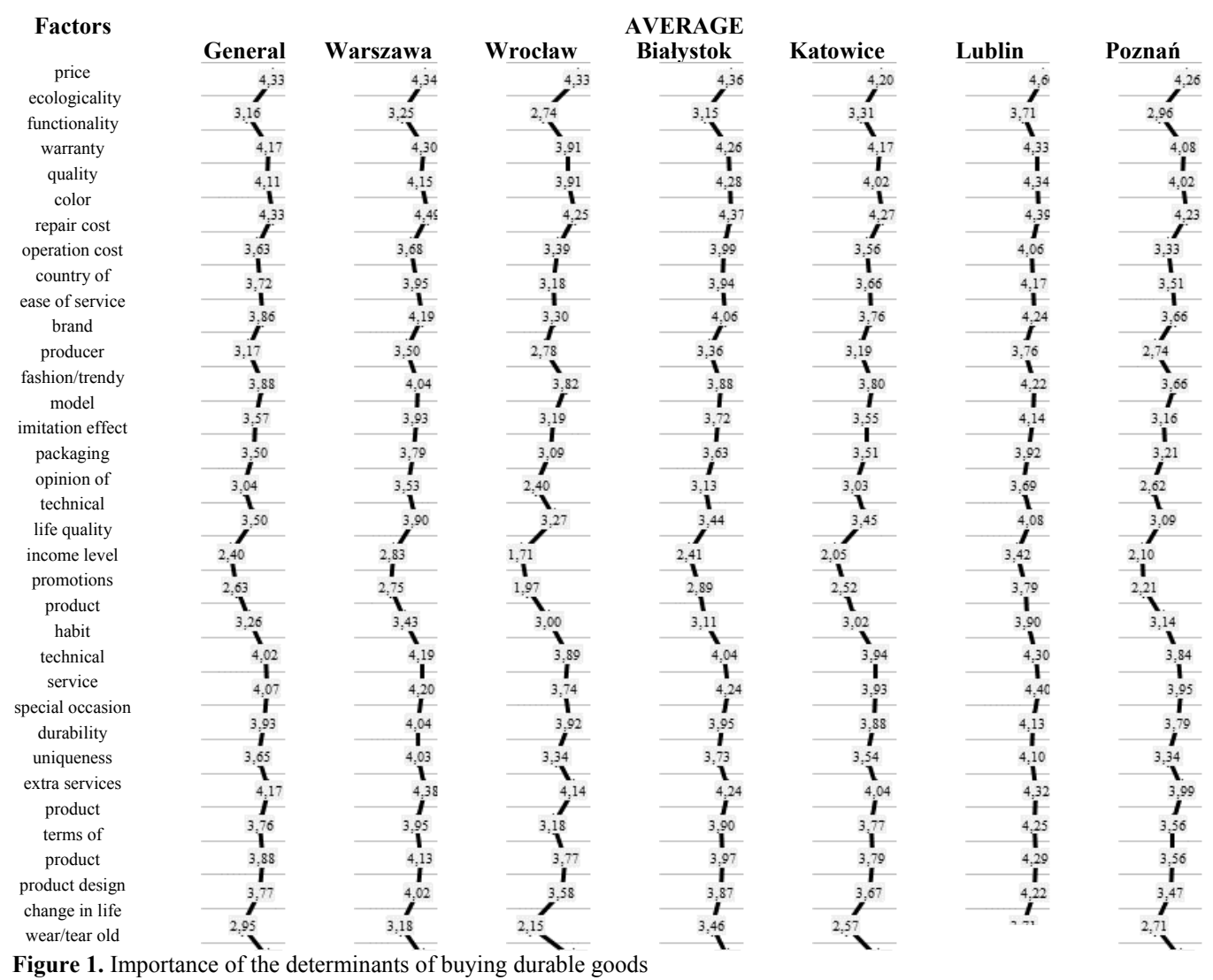

Figure 1. Importance of the determinants of buying durable goods Source: Authors' own research.

Surprisingly low values were also attributed to the following determinants: country of origin $(\bar{x}=3,17)$, brand $(\bar{x}=3,57)$, and producer $(\bar{x}=3,50)$. Those determinants in the past constituted significant premises for the selection of durable goods in Poland. However, globalization, technological progress (modern solutions), comparable value of durable goods 
offered by almost all producers, and the competitiveness of the market portfolio, result in the diminishing role of those factors in the purchasing decisions of the respondents.

We believe that it is the reflection of the growing purchasing maturity of Polish residents of large cities and their much more advanced market experiences. While imitation, special occasions, packaging, or country of origin were essential determinants in purchasing decisions in the 1990s, they are currently much less important, and this trend seems to continue in the future. Elaborating the analysis through the cross-city comparisons, the following previously stated conclusions, concerning the entire studied population (average) were confirmed:

- price level, quality and functionality/usefulness of a durable good were recognized in each examined city as the most crucial purchase determinants;

- the country of origin, producer, and product brand are not significant determinants of purchasing these goods;

- packaging, the effect of imitation, special occasions, and fashion/trends were considered irrelevant in the purchase of these goods.

The next stage of the research process was a comparison of the significance of the purchase determinants of durable goods in the studied cities. With this regard, a one-way analysis of variance ANOVA was used [Wieczorkowska, Wierzbiński, 2011]. This method of comparing the average values of purchase determinants assumed the homogeneity of variance, which allowed to test the hypothesis about equality of mean values in cities. Obtained values of $F$ statistics showed that the variance from all cities is higher than in each examined city.

Therefore, there were reasons to reject the hypothesis about the equality of the average values of the purchase determinants in the examined cities and the claim that in all cities the variability is significantly different (Table 1 ).

Hence, to find differences between cities, it was necessary to use the post hoc test (multiple comparison tests/homogeneous comparison tests $\mathrm{S}-\mathrm{N}-\mathrm{K}^{3}$ ) which allowed identifying groups of cities whose average level of determinants of food purchases differ significantly.

Further, medium groups (the average for the city) were obtained, which for the same group are not significantly different, while the average for cities included in other groups differs significantly (Table 1). In general, the comparison of the significance of purchase determinants of durable goods (average) in the examined cities, showed the existence of statistically significant differences for all factors. On the other hand, a detailed analysis of the results presented in Table 1 allows distinguishing groups of cities that showed similar importance of purchase determinants.

${ }^{3}$ S-N-K - the Student-Newman-Keuls test compares all the averages in pairs using the studentized range distribution (for samples of equal size also performs comparisons with pairs of means within homogeneous subsets, using the step method). The average is sorted from the largest to the smallest, and the largest differences between them are tested first [https://www.ibm.com/support/knowledgecenter/pl]. 
Table 1. Comparison of the importance of the purchase determinants of durable goods

\begin{tabular}{|c|c|c|c|c|c|c|c|}
\hline \multirow{2}{*}{ Factor } & \multicolumn{6}{|c|}{ City } & \multirow{2}{*}{$\underset{\text { p }}{\text { ANOVA F / }}$} \\
\hline & Warszawa & Wroclaw & Białystok & Katowice & Lublin & Poznań & \\
\hline Price & $4,34^{1}$ & $4,33^{1}$ & $4,36^{1}$ & $4,20^{1}$ & $4,60^{2}$ & $4,26^{1}$ & $85,576 * * *$ \\
\hline Ecological aspects & $3,25^{3}$ & $2,74^{1}$ & $3,15^{3}$ & $3,31^{3}$ & $3,71^{4}$ & $2,96^{2}$ & $42,964 * * *$ \\
\hline Functionality & $4,30^{4}$ & $3,91^{1}$ & $4,26^{4}$ & $4,17^{3}$ & $4,33^{4}$ & $4,08^{2}$ & $49,147 * * *$ \\
\hline Warranty & $4,15^{2}$ & $3,91^{1}$ & $4,28^{3}$ & $4,02^{1}$ & $4,34^{3}$ & $4,02^{1}$ & $43,503 * * *$ \\
\hline Product quality & $4,49^{3}$ & $4,25^{1}$ & $4,37^{2}$ & $4,27^{1}$ & $4,39^{2}$ & $4,23^{1}$ & $51,539 * * *$ \\
\hline Colour & $3,68^{2}$ & $3,39^{1}$ & $3,99^{3}$ & $3,56^{2}$ & $4,06^{3}$ & $3,33^{1}$ & $32,080 * * *$ \\
\hline Cost of repair & $3,95^{4}$ & $3,18^{1}$ & $3,94^{4}$ & $3,66^{3}$ & $4,17^{5}$ & $3,51^{2}$ & $45,675 * * *$ \\
\hline Operating costs & $4,19^{5}$ & $3,30^{1}$ & $4,06^{4}$ & $3,76^{3}$ & $4,24^{5}$ & $3,66^{2}$ & $52,194 * * *$ \\
\hline Country of origin & $3,50^{3}$ & $2,78^{1}$ & $3,36^{3}$ & $3,19^{2}$ & $3,76^{4}$ & $2,74^{1}$ & $53,131 * * *$ \\
\hline Ease of use & $4,04^{3}$ & $3,82^{2}$ & $3,88^{2}$ & $3,80^{2}$ & $4,22^{4}$ & $3,66^{1}$ & $26,571 * * *$ \\
\hline Brand & $3,93^{4}$ & $3,19^{1}$ & $3,72^{3}$ & $3,55^{2}$ & $4,14^{5}$ & $3,16^{1}$ & $53,472 * * *$ \\
\hline Producer & $3,79^{3}$ & $3,09^{1}$ & $3,63^{2}$ & $3,51^{2}$ & $3,92^{3}$ & $3,21^{1}$ & $33,833 * * *$ \\
\hline Fashion / trends & $3,53^{4}$ & $2,40^{1}$ & $3,13^{3}$ & $3,03^{3}$ & $3,69^{5}$ & $2,62^{2}$ & $74,236 * * *$ \\
\hline Type & $3,90^{4}$ & $3,27^{2}$ & $3,44^{3}$ & $3,45^{3}$ & $4,08^{5}$ & $3,09^{1}$ & $49,305 * * *$ \\
\hline The effect of imitation & $2,83^{4}$ & $1,71^{1}$ & $2,41^{3}$ & $2,05^{2}$ & $3,42^{5}$ & $2,10^{2}$ & $141,838 * * *$ \\
\hline Packaging & $2,75^{4}$ & $1,97^{1}$ & $2,89^{4}$ & $2,52^{3}$ & $3,79^{5}$ & $2,21^{2}$ & $115,970 * * *$ \\
\hline $\begin{array}{l}\text { Opinion of other } \\
\text { people }\end{array}$ & $3,43^{2}$ & $3,00^{1}$ & $3,11^{1}$ & $3,02^{1}$ & $3,90^{3}$ & $3,14^{1}$ & $31,023 * * *$ \\
\hline Technical parameters & $4,19^{4}$ & $3,89^{2}$ & $4,04^{3}$ & $3,94^{2}$ & $4,30^{4}$ & $3,84^{2}$ & $32,560 * * *$ \\
\hline $\begin{array}{l}\text { Improving the quality } \\
\text { of life }\end{array}$ & $4,20^{3}$ & $3,74^{1}$ & $4,24^{3}$ & $3,93^{2}$ & $4,40^{4}$ & $3,95^{2}$ & $46,118 * * *$ \\
\hline Income level & $4,04^{3}$ & $3,92^{2}$ & $3,95^{3}$ & $3,88^{2}$ & $4,13^{4}$ & $3,79^{1}$ & $9,457 * * *$ \\
\hline Promotion & $4,03^{4}$ & $3,34^{1}$ & $3,73^{3}$ & $3,54^{2}$ & $4,10^{4}$ & $3,34^{1}$ & $43,963 * * *$ \\
\hline $\begin{array}{l}\text { Usefulness of the } \\
\text { product }\end{array}$ & $4,38^{5}$ & $4,14^{2}$ & $4,24^{3}$ & $4,04^{1}$ & $4,32^{4}$ & $3,99^{1}$ & $57,247 * * *$ \\
\hline Habit & $3,95^{4}$ & $3,18^{1}$ & $3,90^{4}$ & $3,77^{3}$ & $4,25^{5}$ & $3,56^{2}$ & $47,947 * * *$ \\
\hline $\begin{array}{c}\text { Technological } \\
\text { solutions }\end{array}$ & $4,13^{4}$ & $3,77^{2}$ & $3,97^{3}$ & $3,79^{2}$ & $4,29^{5}$ & $3,56^{1}$ & $41,532 * * *$ \\
\hline Service & $4,02^{4}$ & $3,58^{1}$ & $3,87^{3}$ & $3,67^{2}$ & $4,22^{5}$ & $3,47^{1}$ & $37,193 * * *$ \\
\hline Special occasion & $3,18^{3}$ & $2,15^{1}$ & $3,46^{4}$ & $2,57^{2}$ & $3,71^{5}$ & $2,71^{2}$ & $92,532 * * *$ \\
\hline Product durability & $4,30^{3}$ & $4,15^{2}$ & $4,21^{2}$ & $4,11^{2}$ & $4,28^{3}$ & $3,98^{1}$ & $47,220 * * *$ \\
\hline $\begin{array}{l}\text { the uniqueness of the } \\
\text { product }\end{array}$ & $3,34^{4}$ & $2,49^{1}$ & $3,42^{4}$ & $3,22^{3}$ & $3,73^{5}$ & $2,71^{2}$ & $64,972 * * *$ \\
\hline Additional services & $3,69^{4}$ & $3,03^{1}$ & $3,46^{3}$ & $3,32^{2}$ & $3,98^{5}$ & $3,01^{1}$ & $46,256 * * *$ \\
\hline Product financing & $3,33^{3}$ & $2,74^{2}$ & $3,38^{3}$ & $2,85^{2}$ & $3,80^{4}$ & $2,62^{1}$ & $55,566 * * *$ \\
\hline Terms of payment & $3,36^{3}$ & $3,11^{2}$ & $3,34^{3}$ & $2,97^{2}$ & $3,88^{4}$ & $2,76^{1}$ & $39,188 * * *$ \\
\hline Product dimensions & $4,00^{3}$ & $3,68^{2}$ & $3,87^{3}$ & $3,25^{1}$ & $4,13^{4}$ & $3,26^{1}$ & $56,056 * * *$ \\
\hline Design & $4,05^{3}$ & $3,75^{2}$ & $4,00^{3}$ & $3,76^{2}$ & $4,20^{4}$ & $3,55^{1}$ & $35,046 * * *$ \\
\hline $\begin{array}{l}\text { Change of life } \\
\text { situation }\end{array}$ & $3,45^{3}$ & $2,53^{1}$ & $3,63^{4}$ & $3,22^{2}$ & $3,82^{4}$ & $3,15^{2}$ & $41,590 * * *$ \\
\hline Product wear/tear & $4,12^{2}$ & $3,91^{1}$ & $4,08^{2}$ & $3,79^{1}$ & $4,17^{2}$ & $3,81^{1}$ & $49,533 * * *$ \\
\hline
\end{tabular}

values $1,2,3 \ldots$ in the upper index means membership in groups due to the importance of the factor in individual cities; F - value of F statistics; $\mathrm{p}$ - level of significance; $* \mathrm{p} \leq 0.05 ; * * \mathrm{p} \leq 0.01 ; * * * \mathrm{p} \leq 0.001$

Source: Authors' own research. 
Table 2 presents groups of cities from 1 to 5 concerning the six determinants which were indicated in the research as the most critical factors of the purchasing process. Table 2 illustrates the level of variation in the assessment of determinants' significance divided into groups, but with similar values achieved in each city. They are also considered the most significant when overall averages are compared.

Referring to the most critical purchase determinants, we can observe that in the case of prices, the group of cities was composed of Warsaw, Wrocław, Katowice, Białystok, Poznań, and Lublin, with the last city performing slightly differently. In other words - surveyed residents in almost every city pointed to the importance of this factor in their decisions of buying durable goods.

Table 2. The most important determinants of the purchase of durable goods by groups of cities

\begin{tabular}{|c|c|c|c|c|c|c|}
\hline \multirow{2}{*}{$\begin{array}{c}\text { Groups of } \\
\text { cities }\end{array}$} & Price & Quality & Durability & Usefulness & Functionality & Warranty \\
\cline { 2 - 7 } & Lublin & Warszawa & $\begin{array}{c}\text { Warszawa } \\
\text { Lublin }\end{array}$ & Warszawa & $\begin{array}{c}\text { Warszawa } \\
\text { Białystok } \\
\text { Lublin }\end{array}$ & $\begin{array}{c}\text { Białystok } \\
\text { Lublin }\end{array}$ \\
\hline \multirow{3}{*}{2} & $\begin{array}{c}\text { Warszawa } \\
\text { Wrocław } \\
\text { Białystok } \\
\text { Katowice } \\
\text { Poznań }\end{array}$ & $\begin{array}{c}\text { Lublin } \\
\text { Białystok }\end{array}$ & $\begin{array}{c}\text { Wrocław } \\
\text { Białystok } \\
\text { Katowic }\end{array}$ & Lublin & Katowice & Warszawa \\
\hline 3 & & $\begin{array}{c}\text { Wrocław } \\
\text { Katowice } \\
\text { Poznań }\end{array}$ & Poznań & Białystok & Poznań & $\begin{array}{c}\text { Poznań } \\
\text { Katowice } \\
\text { Wrocław }\end{array}$ \\
\hline 4 & & & & Wrocław & Wrocław & \\
\hline 5 & & & & $\begin{array}{c}\text { Katowice } \\
\text { Poznań }\end{array}$ & & \\
\hline
\end{tabular}

Source: Authors' own research.

In the case of quality, despite its undoubted importance (high arithmetic mean value), the indications for this factor were different in each city (three groups). On the other hand, the most diversified opinions were identified with regard to the usefulness of durable goods as much as five groups of cities were distinguished. This determinant was the most important for the residents of Warsaw and Lublin

\section{Summary}

Analysis of the determinants of purchase of durable goods allowed to determine the significance of the identified factors and to indicate statistically significant differences in their variability between cities. The presented results of empirical research are confirmed by observations and research results of other institutions and research units, especially those concerning prices and quality of this group of goods. Very low importance of packaging, or the effect of imitation in the case of these goods, was what was expected, but quite a big surprise was the very low assessment of the determinants such as opinions of others (family, 
friends), country of origin, producer, or brand. Nevertheless, in the case of other determinants of this product category, the formulation of unambiguous conclusions is no longer secure, and even in the case of the cities studied, it is possible to talk about the diversity in their meaning and variability.

The results of the empirical research allowed to confirm unambiguously the priority of price and the perceived quality as the main determinants of consumer decisions. From a practical point of view, the usefulness of this type of analysis boils down to two important dimensions:

- identification of the role and significance of the determinants in the purchasing decisions of clients (not only in the spatial aspect - but economic, demographic and social), and the identification of factors that affect the purchasing behavior of potential customers;

- application of the results by companies operating on this product market (durable goods) and their usefulness for shaping market policies and the selection of most useful tools in the marketing and sales of these products.

\section{Bibliography}

Bartkowiak P., Sojkin B., 2014, Determinanty zakupu towarów przez polskich konsumentów, Marketing i Rynek, nr 8.

Bartkowiak P., Sojkin B., 2015, Wyznaczniki decyzji zakupowych towarów przez mieszkańców Poznania i Wielkopolski, Ruch Prawniczy, Socjologiczny i Ekonomiczny, nr 1, Poznań.

Furaji, F; Latuszyńska, M, Wawrzyniak, A., 2012, An Empirical Study of the Factors Influencing Consumer Behavior in the Electric Appliance Market. Vol 6-3.

Hasan A (2014) Consumer Brand Preference for Consumer Durable Goods With Reference to Lucknow District. International Journal of Economics and Management Science 4:217. doi: $10.4172 / 2162-6359.1000217$

Johar, S. 2015, Consumer decision making behavior to purchase of durable goods. International Journal of Applied and Pure Science and Agriculture. Vol 1-15

https://www.ibm.com/support/knowledgecenter/pl

Kowal J., 1998, Metody statystyczne w badaniach sondażowych rynku, Wydawnictwo Naukowe PWN, Warszawa - Wrocław.

Mashao E.T., Sukdeo N., 2018, Factors that influence consumer behavior in the purchase of durable goods household products, Proceedings of the International Conference on Industrial Engineering and Operations Management, Paris, ss.1668-1678.

Neethikumar P. AranganathaT., Determinants of Consumer Behavior towards Durable Goods. A case study of Home Appliances, International Journal of Multi Disciplinary Research - Vol 2 - Issue - 1 January 2014.

Piskiewicz L., M. Radziukiewicz, Zasoby dóbr trwatych $w$ gospodarstwach domowych, Przegląd Statystyczny, GUS, 10/2018.

Ramya N., Ali M., 2016, Factors affecting consumer buying behavior, International Journal of Applied Research 2(10).

Sojkin B., 2015, Determinanty zakupów towarów konsumpcyjnych mieszkańców polskich miast, Marketing i Rynek, nr 8. 
Syndicated Price Image Study 2013, ARC Rynek i Opinia, Vocatus, marzec/ kwiecień.

Sojkin B., 2013, Zachowania zakupowe $i$ konsumpcyjne mieszkańców i Wielkopolski, IBRKiK, Warszawa.

Sojkin B., Bartkowiak P., 2017, Wyznaczniki decyzji zakupowych mieszkańców dużych miast w Polsce w odniesieniu do wybranych towarów FMCG, w: Nauki ekonomiczne w XXI wieku - dylematy, wyzwania, perspektywy. Jubileusz 70-lecia Wydziału Nauk Ekonomicznych Uniwersytetu Ekonomicznego we Wrocławiu / Zając Czesław ( ), 2017, red. Wydawnictwo Uniwersytetu Ekonomicznego we Wrocławiu, ISBN 978-83-7695-665-7, ss.241-250.

Wieczorkowska G., Wierzbiński J., 2011, Statystyka od teorii do praktyki, Wydawnictwo Naukowe Scholar, Warszawa.

Zalega T, 2017, Determinants considered by Polish seniors when purchasing food and some durable goods, Nierówności społeczne a Wzrost Gospodarczy, nr 51 (3/2017).

Zwyczaje zakupowe Polaków, 2013, Shopping Show, Warszawa.

\section{Determinanty zakupu dóbr trwałego użytku przez mieszkańców dużych miast w Polsce}

\section{Streszczenie}

W artykule zaprezentowano analizę czynników zakupu dóbr trwałego użytku w grupach indywidualnych klientów w 6 dużych miastach w Polsce. Analiza oparta została na wynikach badań konsumenckich przeprowadzonych w latach 2016 i 2017 na Uniwersytecie Ekonomicznym w Poznaniu oraz na wynikach innych badań opublikowanych w polskich czasopismach. W wynikach badania zaprezentowano zbiory determinant kształtujące decyzje zakupowe konsumentów dóbr trwałego użytku oraz ich zmienność w latach 2016-2017.

Slowa kluczowe: zachowania nabywcze, determinanty zakupu, analiza wariancji

JEL Codes: D12, D31, M31

$\underline{\text { Information about authors: }}$

prof. dr hab. Bogdan Sojkin

Poznan University of Economics

e-mail: bogdan.sojkin@ue.poznan.pl

ORCID: 0000-0001-5468-8638

dr hab. Magdalena Ankiel

Poznań University of Economics

e-mail: magdalena.ankiel@ue.poznan.pl

ORCID: 0000-0003-2594-1600 